\title{
Pengembangan Bahan Ajar Berbasis TIK Menggunakan Peta Wilayah Untuk Menfasilitasi Kemampuan Pemahaman Konsep Matematis Siswa
}

\author{
Lica Perta Juliyas Muharni ${ }^{1}$, Yenita Roza ${ }^{2}$, Maimunah ${ }^{3}$ \\ 1,2,3 Fakultas Keguruan dan Ilmu Pendidikan, Universitas Riau \\ Jl. Hr. Subrantas Riau, Indonesia \\ Yenita.roza@lecturer.unri.ac.id
}

\begin{abstract}
This study aims to produce mathematics teaching materials based on information and communication technology (ICT) using area maps to facilitate students' ability to understand mathematical concepts. This teaching material is a module packaged in digital form (e-module) interactive with .exe and .3dp formats and can be run offline via computer.This type of research is research and development. The development model used is the ADDIE model. This teaching material is only tested based on the level of validity and practicality. The instruments used in this study were validation sheets and student response questionnaires. The subjects in this study were students of class VIII Islam As-Shofa Pekanbaru. The results of the validity test of teaching materials showed that the overall average aspect of the material validation was $88.06 \%$ with the "very valid" category and the overall average for the media aspect was $87.71 \%$ with the "very valid" category. As for the results of the practicality level field trials, the teaching materials developed were considered very practical with an average of $83.21 \%$. It can be concluded that mathematics teaching materials based on information and communication technology (ICT) use area maps to facilitate students' ability to understand mathematical concepts developed to meet valid and practical criteria.
\end{abstract}

Keywords: Teaching Materials, ICT-Based, Understanding of Mathematical Concepts.

\begin{abstract}
ABSTRAK
Penelitian ini bertujuan untuk menghasilkan bahan ajar matematika berbasis teknologi informasi dan komunikasi (TIK) menggunakan peta wilayah untuk memfasilitasi kemampuan pemahaman konsep matematis peserta didik. Bahan ajar ini merupakan modul yang dikemas dalam bentuk digital (e-modul) interaktif dengan format .exe dan .3dp serta dapat dijalankan secara offline melalui komputer. Jenis penelitian ini adalah penelitian pengembangan atau research and development. Model pengembangan yang digunakan adalah model ADDIE. Bahan ajar ini hanya diuji berdasarkan tingkat validitas dan praktikalitas. Instrumen yang digunakan dalam penelitian ini adalah lembar validasi dan angket respon peserta didik. Subjek dalam penelitian ini adalah siswa kelas VIII Islam As-Shofa Pekanbaru. Hasil uji validitas bahan ajar diperoleh bahwa rata-rata keseluruhan aspek pada validasi materi adalah $88,06 \%$ dengan kategori "sangat valid"dan rata-rata keseluruhan pada aspek media adalah $87,71 \%$ dengan kategori "sangat valid". Sedangkan untuk hasil uji coba lapangan tingkat kepraktisan menunjukkan bahan ajar yang dikembangkan dinilai sudah sangat praktis dengan rata-rata $83.21 \%$. Dapat disimpulkan bahwa bahan ajar matematika berbasis teknologi informasi dan komunikasi (TIK) menggunakan peta wilayah untuk memfasilitasi kemampuan pemahaman konsep matematis peserta didik yang dikembangkan memenuhi kriteria valid dan praktis.
\end{abstract}

Kata kunci : Bahan Ajar, Berbasis TIK, Pemahaman Konsep Matematis.

Copyright (c) 2021 Lica Perta Juliyas Muharni, Yenita Roza, Maimunah

$\triangle$ Corresponding author: Yenita Roza

Email Address: yenita.roza@lecturer.unri.ac.id (Jl. H.R Soebrantas, Riau)

Received 28 November 2020, Accepted 15 Februari 2021, Published 17 Februari 2021

\section{PENDAHULUAN}

Kecakapan atau kemampuan matematis yang ada pada diri peserta didik merupakan hasil dari adanya mata pelajaran matematika. Salah satu kemampuan matematis yaitu kemampuan pemahaman konsep matematis. Pemahaman konsep dalam matematika dimaksudkan sebagai kemampuan menangkap makna atau ide-ide pokok dalam matematika. Peserta didik lebih mudah dalam mempelajari matematika jika menguasai konsep yang mana konsep merupakan dasar yang menjadi 
landasan dalam memahami dan menyelesaikan permasalahan permasalahan yang terdapat dalam matematika.

Kurikulum pendidikan di Indonesia menjadikan kemampuan pemahaman konsep matematis sebagai salah satu tujuan dalam pembelajaran matematika. Salah satu upaya untuk mewujudkan tujuan tersebut adalah menyediakan bahan ajar yang dapat menjadi sumber belajar bagi peserta didik agar tercapainya tujuan pembelajaran. Bahan ajar tesebut dapat didesain khusus sesuai dengan kebutuhan agar peserta didik dapat terbantu dalam memahami konsep-konsep matematis sebagaimana yang telah diungkapkan (Sulistyosari, 2018) bahwa guru dapat menciptakan proses pembelajaran yang efektif dengan membuat bahan ajar yang sesuai dengan kebutuhan belajar peserta didik.

Menurut (Mudlofir, 2011) bahan ajar yaitu suatu bahan yang telah disusun baik dalam bentuk tertulis maupun dalam bentuk tidak tertulis yang dapat digunakan pada kegiatan pembelajaran. Hal yang sama di ungkapkan oleh (Majid, 2013) bahwa bahan ajar adalah sekumpulan materi yang digunakan sebagai alat informasi baik dalam bentuk tertulis maupun tidak tertulis yang digunakan guru dalam proses pembelajaran. Berdasarkan pendapat tersebut, ditarik kesimpulan bahwa bahan ajar merupakan suatu bahan baik berupa seperangkat materi ataupun alat informasi yang digunakan oleh guru maupun peserta didik dalam proses pembelajaran.

Ungkapan (Ianah \& Raharjo, 2014) bahwa kebanyakan bahan ajar yang tersedia dan sering digunakan adalah bahan ajar cetak berupa berupa buku paket yang didalamnya terdapat materi yang sulit dipelajari pada saat menyampaikan materi. Hal ini dikarenakan kebanyakan buku cetak matematika yang beredar dipasaran menggunakan bahasa yang sulit dipahami oleh peserta didik sehingga membuat peserta didik malas dan hanya menatapi buku yang kurang menarik bagi peserta didik dengan rasa kebosanan. Sejalan dengan penemuan tersebut (Hidayati, A. Bentri, A. Sunarti, 2019) juga mengungkapkan bahwa peserta didik cenderung menggunakan bahan ajar berupa buku cetak dari penerbit-penerbit umum sebagai sumber belajar yang mana buku tersebut banyak yang tidak sesuai dengan perkembangan aspek berpikir anak dan hanya menekankan pada kemampuan menghafal saja. (Roza et al., 2018) juga mengungkapkan bahwa buku yang telah disediakan oleh pemerintah didesain dengan tujuan bersifat nasional sehingga perlulah guru menggunakannya menyesuaikan karakteristik peserta didik disekolah masing-masing. Hal ini juga ditemukan di SMP Islam As-Shofa Pekanbaru dimana sekolah tersebut guru maupun peserta didik menggunakan bahan ajar berupa buku cetak matematika Mandiri kurikulum 2013 yang merupakan hasil dari suatu penerbit. Pada umumnya buku yang digunakan tersebut hanya berisi ringkasan materi, kumpulan rumus-rumus, contoh soal, dan latihan soal yang minim penjelasan. Buku tersebut juga tidak menuntun pesarta didik untuk memahami konsep matematika pada materi yang diajarkan.

Penyusunan materi pada bahan ajar merujuk pada silabus yang telah disusun (Syaiful, 2008). Penyusunan materi bahan ajar juga mempertimbangkan alokasi waktu yang dibutuhkan untuk mencapai tujuan pembelajaran yang telah tertuang pada silabus. Pada umumnya alokasi waktu yang 
tertuang dalam silabus merupakan perkiraan waktu rerata untuk menguasai kompetensi pencapaian yang dibutuhkan oleh peserta didik yang beragam (Peraturan Menteri Pendidikan dan Kebudayaan, 2013). Bagi peserta didik yang sulit untuk memahami materi memungkinkan alokasi waktu yang ditetapkan tersebut tidak cukup untuk mencapai tujuan pembelajaran yang diinginkan. Karena itu seorang guru harus mempertimbangkan hal tersebut dalam memilih atau menyusun bahan ajar yang tepat sebagai sumber belajar peserta didik agar tercapainya pembelajaran yang efektif dan efisien. Salah satu alternative cara yang dapat digunakan adalah memilih bahan ajar dengan pemanfaatan TIK sebagaimana yang diungkapkan oleh (Tekege, 2017) pemanfaatan TIK sangat membantu guru dalam proses pembelajaran, sehingga ketercapaian tujuan pembelajaran yang efektif dan efisien. Hal ini sejalan dengan (Peraturan Menteri Pendidikan dan Kebudayaan No.22, 2016) bahwa prinsip pembelajaran dengan memanfaatkan teknologi informasi dan komunikasi dapat digunakan untuk meningkatkan efisiensi dan efektivitas pembelajaran.

Guru dapat mengembangkan bahan ajar dengan pemanfaatan TIK melalui penggunaan teknologi multimedia interaktif yang menjadi salah satu karakteristik sebagai bahan ajar TIK dalam proses pembelajaran (Rahmadani et al., 2018). Multimedia interaktif merupakan penggabungan gambar, video, animasi, dan audio dalam satu perangkat lunak (software) yang memungkinkan pengguna untuk berinteraksi secara langsung. Teknologi multimedia diharapkan dapat mengatasi masalah-masalah dalam proses pembelajaran. Multimedia interaktif dapat menyajikan konsep dengan tampilan yang menarik akibat penggabungan antara gambar, animasi, bahkan audio yang menarik. Dengan tampilan seperti itu, rasa bosan yang dialami peserta didik karena pembelajaran yang monoton akan dapat berkurang, sehingga peserta didik akan lebih tertarik untuk memahami materi yang diberikan (Novitasari, 2016). Hal ini sesuai dengan "teori kognitif tentang multimedia learning, menyajikan materi dengan memanfaatkan multimedia memiliki kemampuan untuk menghasilkan pembelajaran dan pemahaman lebih mendalam jika dibandingkan dengan materi disajikan hanya dalam satu format" (Richard. E. Mayer, 2009).

Berdasarkan uraian yang telah dipaparkan peneliti melakukan inovasi dengan upaya mengembangkan bahan ajar dengan memanfaatkan Teknologi Informasi dan Komunikasi (TIK) dalam bentuk e-modul interaktif sebagai salah satu alternative sumber belajar yang dapat digunakan dalam proses pembelajaran untuk memfasilitasi pemahaman konsep matematis siswa. Sebagaimana yang diungkapkan oleh (Rahmadani et al., 2018) dan (Mardyansyah et al., 2013) bahwa menggunakan bahan ajar dengan memanfaatkan teknologi informasi dan komunikasi (TIK) pada proses pembelajaran dapat menumbuhkembangkan pemahaman konsep matematika, menumbuhkan minat dan motivasi peserta didik dalam belajar serta dapat meningkatkan inovasi, kreativitas, dan kemandirian peserta didik.

Pada (Peraturan Daerah Provinsi Riau No. 12, 2013) yang menetapkan bahwa satuan pendidikan formal dan nonformal wajib mengajarkan mata pelajaran muatan lokal budaya Melayu Riau yang diintegrasikan dalam mata pelajaran lainnya. Peraturan daerah ini sejalan dengan kebijakan 
pada kurikulum 2013 yang tertuang dalam (Peraturan menteri pendidikan No. 79, 2014) yang dijelaskan bahwa muatan lokal merupakan bahan kajian atau mata pelajaran pada satuan pendidikan yang berisi pembelajaran mengenai potensi dan keunikan lokal untuk membentuk pemahaman peserta didik terhadap keunggulan dan kearifan di daerah tempat tinggalnya. Tujuan muatan lokal diajarkan untuk membekali siswa dengan sikap,pengetahuan, dan keterampilan yang diperlukan untuk mengenal dan mencintai lingkungan alam, sosial, budaya, dan spiritual di daerahnya. Agar peraturan daerah tersebut dapat terlaksana, salah satu cara yang dapat digunakan yaitu mengintegrasikan muatan lokal kedalam mata pelajaran matematika melalui peta wilayah Riau. Menurut (Nurjehan, 2017) mengintegrasikan budaya ke dalam proses pendidikan juga diyakini mampu menciptakan pembelajaran yang lebih bermakna melalui pengalaman yang ditemui siswa di kehidupan sehariharinya.

Pada mata pelajaran matematika terdapat materi koordinat kartesius yang memungkinkan untuk mengintegrasikan peta wilayah Riau. Materi ini disajikan melalui KD 3.2 dan KD 4.2 untuk kelas VIII. Peta adalah gambaran permukaan bumi dalam satu bidang datar yang memiliki keunggulan untuk memberi pengetahuan dan pengalaman kepada peserta didik baik dalam posisi geografis, keadaan alam serta persebaran penduduk di daerah/lokasi tertentu (Bagja Waluya, 2015). Peta wilayah dapat digunakan sebagai alat bantu untuk membantu mempelajari kondisi suatu wilayah (Said et al., 2017). Suatu titik pada peta yang dinyatakan dengan koordinat mengacu pada sistem koordinat yang didefinisikan sebagai berikut: (1) lokasi titik asal (titik nol) dari sistem koordinat; (2) orientasi dari sumbu-sumbu koordinat; (3) besaran yang digunakan untuk mendefinisikan posisi suatu titik dalam sistem koordinat tersebut (Basaria et al., 2018). Hal ini lah menjadi alasan peta wilayah digunakan sebagai ilustrasi dalam penyajian masalah pada bahan ajar untuk memperoleh pemahaman terhadap materi yang dipelajari dan juga melalui peta wilayah, muatan lokal dapat diintergrasikan dalam pelajaran matematika. Oleh karena itu peneliti melakukan pengembangan bahan ajar berbasis TIK dalam bentuk e-modul interaktif dengan mengunakan peta wilayah Riau sebagai ilustrasi dalam penyajian masalah pada bahan ajar untuk memfasilitasi kemampuan pemahaman konsep matematis peserta didik pada materi koordinat kartesius.

\section{METODE}

Jenis penelitiam yang digunakan dalam penelitian ini adalah penelitian pengembangan (Research and Development/ $R \& D$ ) yang bertujuan untuk menghasilkan bahan ajar matematika berbasis teknologi informasi dan komunikasi menggunakan peta wilayah untuk menfasilitasi kemampuan pemahaman konsep matematika siswa pada materi koordinat kartesius. Model pengembangan yang digunakan adalah ADDIE yang meliputi tahap (1) analisis; (2) desain; (3) pengembangan; (4) implementasi; (5) evaluasi. Kegiatan yang dilakukan di setiap tahap ADDIE dapat dilihat pada gambar 1 berikut. 


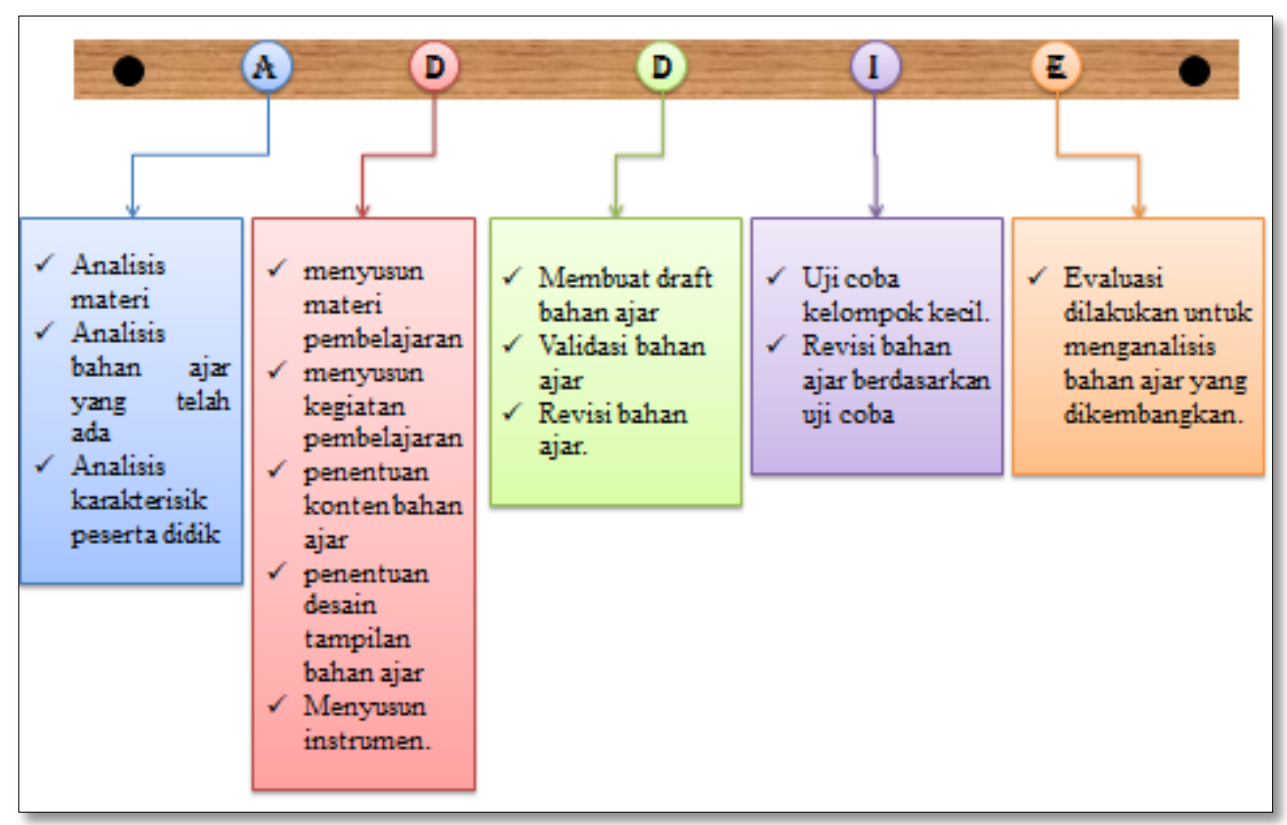

Gambar 1. Tahapan ADDIE dalam Mengembangkan Bahan Ajar Berbasis TIK Menggunakan Peta Wilayah

Subjek uji coba dalam penelitian ini adalah 6 peserta didik kelas VIII SMP Islam As-Shofa Pekanbaru yang terdiri dari ketentuan peserta didik terdiri dari 2 orang berkemampuan tinggi, 2 orang berkemampuan sedang, dan 2 orang berkemampuan rendah. Waktu penelitian tahun ajaran 2019/2020 semester 2. Instrumen pengumpulan data dalam penelitian ini adalah lembar validasi dan angket respon peserta didik. Lembar validasi terdiri dari lembar validasi materi (berdasarkan aspek kelayakan isi, kelayakan penyajian, dan penilaian bahasa) dan lembar validasi media (berdasarkan aspek kelayakan kegrafisan dan kelayakan program). Tiap indikator pada lembar validasi terdiri dari lima alternative jawaban yaitu 1, 2, 3, 4,dan 5 yang masing-masing dengan kategori sangat kurang baik, kurang baik, cukup baik, baik, dan sangat baik. Adapun angket respon peserta didik meliputi aspek kemudahan penggunaan bahan ajar, penampilan, penyajian, dan keterbacaan. Tiap indikator angket respon peserta didik terdiri dari empat alternative jawaban yaitu 1, 2, 3, dan 4 yang masing-masing dengan kategori sangat kurang setuju, kurang setuju, setuju, dan sangat setuju. Analisis data yang dilakukan pada penelitian ini adalah analisis data kuantitatif dan analisis data kualitatif. Analisis data kuantitatif dilakukan untuk mendeskripsikan validitas dan praktikalitas bahan ajar berbasis TIK menggunakan peta wilayah. Data hasil validasi yang diperoleh dari lembar validasi dan data pratikalitas yang diperoleh dari angket respon siswa dianalisis menggunakan rumussebagai berikut.

$V_{p}=\frac{T_{s v}}{T_{s m}} \times 100 \%$

Keterangan :

$V_{p} \quad:$ Persentase rata-rata pada tiap aspek

$T_{s v} \quad:$ Total skor empiris dari validator

$T_{\text {sh }} \quad$ : Total skor maksimal yang diharapkan

Sumber:(Sa'adul Akbar, 2013) 
Untuk mengetahui hasil akhir analisis data validitas dan analisis data praktikalitas bahan ajar maka dihitung dengan menggunakan rumus rata-rata (mean). Untuk mengetahui kriteria validitas dapat dilihat pada Tabel 1 berikut:

Tabel 1. Kriteria Validitas

\begin{tabular}{|c|c|}
\hline Interval & Tingkat Validitas \\
\hline $81 \%-100 \%$ & Sangat Valid \\
\hline $61 \%-80 \%$ & Valid \\
\hline $41 \%-60 \%$ & Cukup Valid \\
\hline $21 \%-40 \%$ & Kurang Valid \\
\hline $0 \%-20 \%$ & Tidak Valid \\
\hline
\end{tabular}

Modifikasi: (Riduwan, 2013)

Bahan ajar matematika berbasis TIK menggunakan peta wilayah dikatakan valid jika termasuk dalam kategori valid atau sangat valid. Sedangkan untuk mengetahui kriteria praktikalitas dapat dilihat pada Tabel 2 berikut:

Tabel 2. Kriteria Praktikalitas

\begin{tabular}{|c|c|}
\hline Interval & Tingkat Kepraktisan \\
\hline $81 \%-100 \%$ & Sangat Praktis \\
\hline $61 \%-80 \%$ & Praktis \\
\hline $41 \%-60 \%$ & Cukup Praktis \\
\hline $21 \%-40 \%$ & Kurang Praktis \\
\hline $0 \%-20 \%$ & Tidak Praktis \\
\hline
\end{tabular}

Sumber:(Nurhamdiah et al., 2020)

Bahan ajar matematika berbasis TIK menggunakan peta wilayah dikatakan praktis jika termasuk dalam kategori praktis atau sangat praktis. Adapun data analisis data kualitatif diperoleh dari masukan atau tanggapan dari validator dan peserta didik terhadap bahan ajar berbasis TIK menggunakan peta wilayah. Tanggapan atau masukan yang diperoleh dari validator dan peserta didik yang bersifat membangun dan dianggap tepat digunakan sebagai bahan perbaikan pada tahan revisi bahan ajar.

\section{HASIL DAN DISKUSI}

\section{Hasil}

\section{Tahap Analisis}

Pada tahap analisis ada beberapa hal yang dilakukan yaitu: analisis materi, analisis, karakteristik siswa dan analisis bahan ajar yang telah ada.

\section{Analisis Materi}

Analisis materi dilakukan dengan cara menganalisis materi koordinat kartesius berdasarkan pada kurikulum 2013 KD. 3.2 dan KD 4.2. Berdasarkan kompetensi dasar diatas, peneliti menyusun materi koordinat kartesius menjadi tiga materi pembelajaran. Adapun materi koordinat kartesius yang harus dikuasai siswa pada KD tersebut antara lain: (1) menentukan posisi titik terhadap sumbu- $x$ dan sumbu-y;(2) menentukan posisi titik terhadap titik asal $(0,0)$ dan titik tertentu $(a, b) ;(3)$ menentukan posisi garis terhadap sumbu- $x$ dan sumbu-y (4) menyelesaikan masalah yang berkaitan dengan 
kedudukan titik dalam bidang koordinat kartesius. Analisis materi ini dilakukan dengan cara studi dokumentasi.

Analisis bahan ajar yang telah ada

Berdasarkan studi dokumentasi yang dilakukan peneliti pada guru SMP Islam As-Shofa Pekanbaru mengenai bahan ajar yang digunakan pada proses pembelajaran, sekolah tersebut saat ini mengunakan buku matematika Mandiri kurikulum 2013 dalam proses pembelajaran yang merupakan hasil dari suatu penerbit. Buku tersebut hanya menampilkan ringkasan materi berupa kumpulan rumus-rumus singkat yang sulit dimengerti oleh peserta didik secara mandiri. Selain itu buku tersebut juga hanya menampilkan contoh soal yang tidak berhubungan dengan situasi nyata sehingga menjadikan materi koordinat kartesius tidak penting bagi peserta didik.

Selain buku matematika Mandiri kurikulum 2013, sekolah lain yang ada dipekanbaru juga menggunakan buku Erlangga. Pada buku Erlangga khususnya materi koordinat kartesius, contoh soal koordinat kartesius telah memanfaatkan peta wilayah di dalamnya yaitu peta wilayah Jambi dan Jawa, akan tetapi bahan ajar yang diharapkan yaitu bahan ajar yang sesuai dengan tuntutan Perda Prov. Riau No.12 Tahun 2013 yakni bahan ajar bahan ajar yang mengintegrasikan muatan lokal budaya melayu Riau sehingga peta wilayah Jambi dan Jawa kurang pas untuk dimanfaatkan sebagai media dalam bahan ajar yang akan digunakan oleh peserta didik yang ada dikawasan Riau untuk mencapai tujuan pembelajaran muatan lokal yaitu untuk membekali peserta didik dengan sikap, pengetahuan, dan keterampilan untuk mengenal dan mencintai lingkungan alam, sosial, budaya, dan spiritual di daerahnya (Permendikbud No. 79 Tahun 2014).

Analisis karakteristik peserta didik.

Pada tahap ini yaitu mengidentifikasi karakteristik peserta didik dengan tujuan untuk menyesuaikan produk yang dikembangkan dengan kebutuhan peserta didik. Identifikasi karakteristik peserta didik diperoleh dari studi dokumentasi dan wawancara pada salah satu sekolah SMP yang ada di Pekanbaru. Berdasarkan hasil studi dokumentasi, karakteristik peserta didik SMP rata-rata memiliki usia 11-14 tahun, yang mana pada usia tersebut motivasi belajar peserta didik dapat meningkat apabila guru memanfaatkan media berbentuk digital dalam proses pembelajaran (Mawarni \& Muhtadi, 2017). Adapun hasil wawancara yang dilakukan kepada salah satu guru di SMP As-Shofa Pekanbaru menyatakan kemampuan peserta didik di sekolah tersebut memiliki kecepatan yang berbeda-beda untuk memahami materi pelajaran. Ada yang cepat dalam memahami materi pelajaran, adapula yang sedang dan lambat dalam memahami materi pelajaran. Berdasarkan karakteristik tersebut, pengembangan bahan ajar berbasis TIK dinilai tepat agar dapat digunakan sebagai sumber belajar. Hal ini dikarenakan menggunakan bahan ajar berbasis TIK dapat mendukung kecepatan peserta didik dalam belajar (Macarandang, 2009).

\section{Tahap Desain}


Adapun yang dilakukan peneliti pada tahap ini yaitu mendesain materi pembelajaran, mendesain kegiatan belajar dan mendesain tampilan bahan ajar. Berikut ini penjelasan mengenai kegiatan yang dilakukan peneliti pada tahap desain.

\section{Desain Materi Pembelajaran}

Materi pembelajaran yang akan dikembangkan pada bahan ajar berbasis TIK disusun sesuai dengan analisis yang telah dilakukan. Desain materi pembelajaran pada bahan ajar disesuaikan pada KD 3.2 dan KD 4.2 pada materi koordinat kartesius. Adapun materi pembelajaran meliputi posisi titik terhadap sumbu- $x$ dan sumbu- $y$, posisi titik terhadap titik asal $(0,0)$ dan titik tertentu $(a, b)$ serta posisi garis terhadap sumbu- $x$ dan sumbu- $y$. Pada materi posisi titik terhadap sumbu- $x$ dan sumbu- $y$ terbagi menjadi tiga sub materi yaitu posisi objek pada bidang koordinat, posisi titik terhadap sumbu- $x$ dan sumbu- $y$ dan kuadran pada bidang koordinat. Pada materi posisi titik terhadap titik asal $(0,0)$ dan titik tertentu $(a, b)$ dibagi menjadi dua sub materi yaitu posisi titik terhadap titik asal $(0,0)$ dan posisi titik terhadap titik tertentu $(a, b)$. Sedangkan pada materi posisi garis terhadap sumbu- $x$ dan sumbu- $y$ dibagi menjadi dua sub materi yaitu garis sejajar atau tegak lurus terhadap sumbu- $x$ dan sumbu- $y$ dan garis berpotongan terhadap sumbu- $x$ dan sumbu- $y$.

\section{Desain Kegiatan Belajar}

Materi pembelajaran yang telah didesain tersebut kemudian dibagi menjadi tiga kegiatan belajar. Hal ini dilakukan untuk menyesuaikan materi yang akan dipelajari dengan waktu yang tersedia. pada kegiatan belajar 1 akan membahas materi posisi objek pada bidang, posisi titik terhadap sumbu- $x$ dan sumbu- $y$, dan kuadran pada bidang koordinat. Pada kegiatan belajar 2, materi yang akan dibahas yaitu posisi titik terhadap titik asal $(0,0)$ dan posisi titik terhadap titik tertentu $(a, b)$. Sedangkan untuk kegiatan belajar 3 akan membahas materi garis sejajar atau tegak lurus terhadap sumbu- $x$ dan sumbu- $y$ dan garis berpotongan terhadap sumbu- $x$ dan sumbu- $y$.

\section{Desain Tampilan Bahan Ajar}

Pada tahap ini, peneliti mendesain tampilan bahan ajar keseluruhan pada bahan ajar berbasis TIK menggunakan peta wilayah yang akan dikembangkan. Desain tampilan bahan ajar yang dikembangkan meliputi pembuatan cover, cover bagian dalam, kata pengantar, daftar isi, petunjuk penggunaan, petunjuk belajar, Kompetensi Inti (KI) dan Kompetensi Dasar (KD), kisi-kisi soal, peta konsep, kamu harus tahu, sejarah materi, kegiatan belajar, rangkuman, uji kompetensi, daftar pustaka, daftar penulis, cover belakang e-modul.

\section{Tahap Pengembangan}

Selama fase pengembangan, materi pembelajaran, kegiatan belajar serta komponen-komponen e-modul yang telah dirancang direalisasikan ke bentuk nyata. E-modul dikembangkan dengan memadukan unsur-unsur seperti animasi, gambar,video, bahan-bahan berupa grafik,dan tombol navigasi secara harmonis untuk menghasilkan tampilan yang bagus dan menarik. Berikut gambar tampilan e-modul yang telah di kembangkan. 


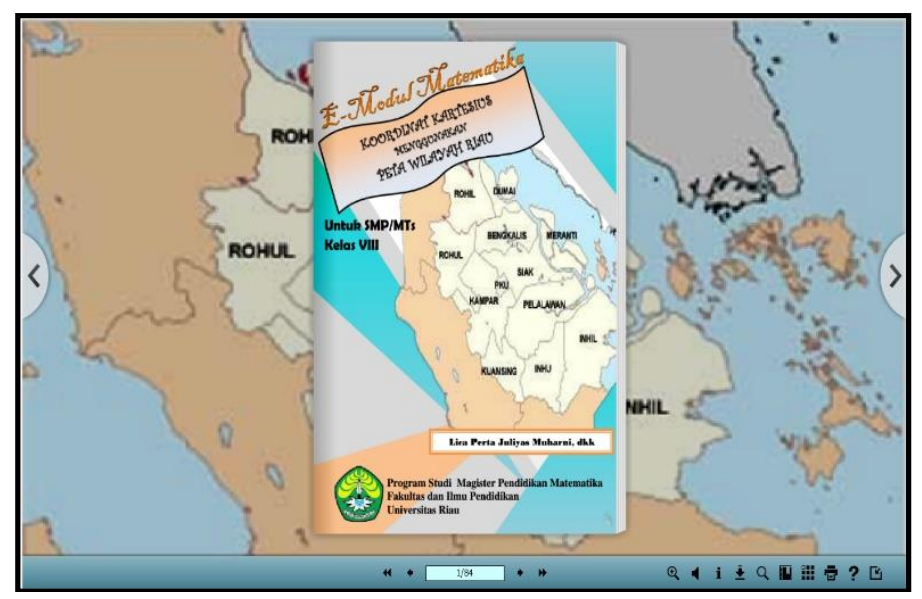

Gambar 2. Cover e-Modul

Video animasi pada e-modul dikemas dengan menggunakan Bandicam sedangkan gambar dikemas dengan menggunakan Microsoft Power Point 2010. Kemudian semuanya disatukan dengan menggunakan Software 3D Pageflip Pro. Berikut ini tampilan video dan gambar pada e-modul.

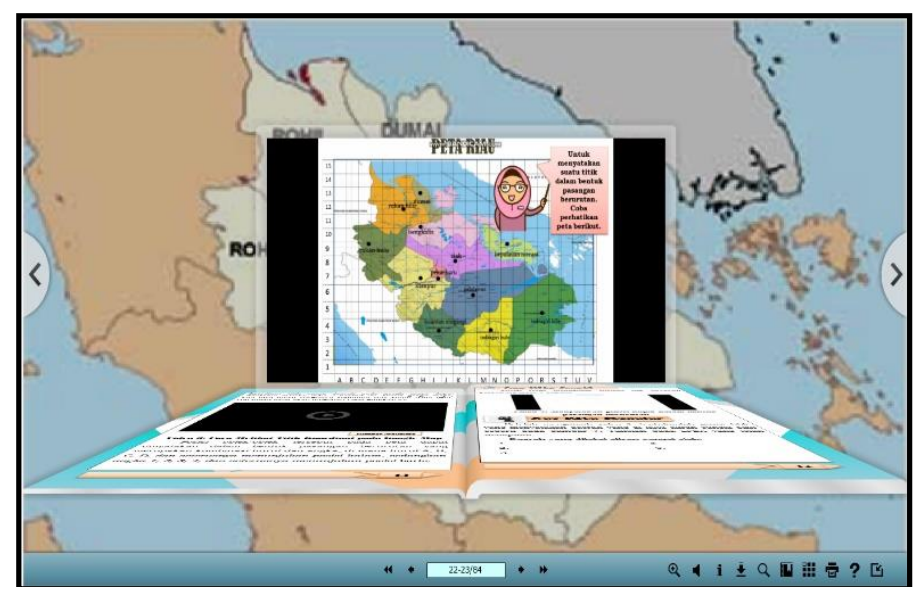

Gambar 3. Hasil Revisi Tampilan Video

E-modul yang telah dikemas dalam bentuk aplikasi kemudian divalidasi oleh tiga orang validator yang terdiri dari dua orang dosen pendidikan matematika dan seorang guru bidang studi matematika. E-modul dinilai menggunakan lembar validasi materi dan lembar validasi media. Adapun hasil validasi e-modul berdasarkan lembar validasi materi dapat dilihat pada tabel 3 berikut.

Tabel 3. Hasil Validasi Materi

\begin{tabular}{|c|l|c|c|}
\hline No. & \multicolumn{1}{|c|}{ Aspek } & Rata-rata & Kategori \\
\hline 1 & Kelayakan Isi & $86,67 \%$ & Sangat Valid \\
\hline 2 & Kelayakan Penyajian Materi & $92,50 \%$ & Sangat Valid \\
\hline 3 & Kelayakan Bahasa & $85,00 \%$ & Sangat Valid \\
\hline \multicolumn{2}{|c|}{ Rata-rata } & $\mathbf{8 8 , 0 6 \%}$ & Sangat Valid \\
\hline
\end{tabular}

Berdasarkan tabel 1 terlihat bahwa ada tiga aspek yang divalidasi yaitu aspek kelayakan isi, aspek kelayakan penyajian materi dan aspek kelayakan bahasa. Berdasarkan hasil validasi e-modul diperoleh untuk aspek kelayakan isi dengan rata-rata $86,67 \%$ dengan kategori sangat valid, aspek 
kelayakan penyajian materi $92,50 \%$ dengan kategori sangat valid dan aspek kelayakan bahasa 85,00\% dengan kategori sangat valid. Dari ketiga aspek tersebut terlihat bahwa rata-rata yang diperoleh berada pada kategori sangat valid dan bisa digunakan dalam penelitian ini. Adapun hasil validasi e-modul berdasarkan lembar validasi media dapat dilihat pada tabel 4 berikut.

Tabel 4. Hasil Validasi Media

\begin{tabular}{|c|l|c|c|}
\hline No. & Aspek & Rata-rata & Kategori \\
\hline 1 & Kelayakan Kegrafisan & $84,58 \%$ & Sangat Valid \\
\hline 2 & Kelayakan Program & $90,83 \%$ & Sangat Valid \\
\hline \multicolumn{2}{|c|}{ Rata-rata } & $\mathbf{8 7 , 7 1 \%}$ & Sangat Valid \\
\hline
\end{tabular}

Berdasarkan tabel 4 terlihat bahwa ada dua aspek yang divalidasi yaitu kelayakan kegrafisan dan kelayakan program. Berdasarkan hasil validasi e-modul diperoleh untuk aspek kelayakan kegrafisan memiliki rata-rata $84,58 \%$ dengan kategori sangat valid dan aspek kelayakan program memiliki rata-rata adalah 90,83\% dengan kategori sangat valid. Dari kedua aspek tersebut terlihat bahwa rata-rata yang diperoleh berada pada kategori sangat valid dan bisa digunakan dalam penelitian ini. Setelah divalidasi, e-modul pembelajaran direvisi dan diperbaiki berdasarkan saran dan koreksi dari validator. Berikut ini perbaikan-perbaikan yang telah di lakukan peneliti mengenai saran dan koreksi dari validator yaitu: (1) melakukan perubahan warna pada e-modul dengan menggunakan warna dominan biru agar tidak terlihat terang dan menyilaukan mata;(2) melakukan perubahan warna tombol navigasi/ visible Button dengan menggunakan warna hitam agar tampilan cukup tajam dan tidak mengaburkan pandangan pemakai ketika akan memilih menu yang diinginkan;(3) melakukan perubahan pada kata "provinsi" pada paragrap pertama pada halaman 3 dengan kata "kabupaten"karena terjadi salah pengetikan kata; (4) melakukan pertajaman tampilan video dengan meredupkan tampilan backround agar tampilan video lebih muncul saat di putar; (5) melakukan perubahan kegiatan belajar pada bagian "Ayo kita berbagi”, menjadi "Ayo kita cek hasilnya" agar dapat digunakan dan sesuai pada kondisi COVID-19 saat ini; (6) melengkapi e-modul dengan kunci jawaban sebagai evaluasi siswa apakah diperkenankan untuk melanjutkan kegiatan belajar pada modulnya atau harus kembali berlatih agar lebih sesuai dengan pembelajaran online pada saat sekarang ini; (7) melakukan penambahan tanggal kapan diakses setiap link yang dari internet seperti pada bada bagian daftar pustaka;(8) menambahkan e-modul dengan kata-kata motivasi serta emoticon sebagai atau pujian jika mereka berhasil atau tidaknya mengerjakan soal latihan agar lebih menarik dan sesuai dengan karakteristik siswa SMP.

\section{Tahap Implementasi}

Setelah melewati tahap validasi bahan ajar oleh validator, kemudian dilakukan revisi sesuai saran validator, e-modul kemudian diujicobakan kepada peserta didik SMP Islam As-Shofa Pekanbaru untuk melihat uji keterbacaan e-modul. Adapun hasil angket pada tahap ujicoba terhadap peserta didik dipaparkan pada tabel 5 berikut ini. 
Tabel 5. Hasil Penilaian Ujicoba Lapangan

\begin{tabular}{|l|l|c|c|}
\hline No & \multicolumn{1}{|c|}{ Aspek } & Rata-rata (\%) & Kategori \\
\hline 1. & Penggunaan bahan ajar & 88.54 & Sangat Praktis \\
\hline 2. & Tampilan & 80.95 & Sangat Praktis \\
\hline 3. & Penyajian & 79.17 & Praktis \\
\hline 4. & Keterbacaan & 84.17 & Sangat Praktis \\
\hline \multicolumn{2}{|c|}{ Rata-rata Keseluruhan (\%) } & $\mathbf{8 3 . 2 1}$ & Sangat Praktis \\
\hline
\end{tabular}

Berdasarkan tabel 5 terlihat bahwa ada empat aspek yang dinilai yaitu aspek penggunaan bahan ajar, aspek tampilan, aspek penyajian, dan aspek keterbacaan. Berdasarkan hasil ujicoba lapangan e-modul diperoleh untuk aspek kemudahan penggunaan bahan ajar memiliki rata-rata $88.54 \%$ dengan kategori sangat praktis, aspek tampilan memiliki rata-rata $80.95 \%$ dengan kategori sangat praktis, aspek penyajian memiliki rata-rata $79.17 \%$ dengan kategori praktis, dan aspek keterbacaan memiliki rata-rata $84.17 \%$ dengan kategori sangat praktis. Dari keempat aspek tersebut terlihat bahwa rata-rata yang diperoleh berada pada kategori sangat praktis dan layak digunakan proses pembelajaran.

\section{Tahap Evaluasi}

Penelitian ini merupakan penelitian pengembangan yang memiiliki tujuan untuk menghasilkan bahan ajar matematika berbasis teknologi informasi dan komunikasi (TIK) menggunakan peta wilayah Riau untuk menfasilitasi kemampuan pemahaman konsep siswa pada kompetensi dasar 3.2 dan 4.2. Bahan ajar yang dikembangkan berupa e-modul yang dikemas dalam bentuk aplikasi yang dapat digunakan dan dijalankan secara offline oleh guru dan peserta didik. Bahan ajar ini memiliki komponen berikut yakni cover, kata pengantar, petunjuk penggunaan, petunjuk belajar, kisi-kisi indikator soal, daftar isi, kompetensi inti, kompetensi dasar, tujuan pembelajaran, peta konsep, sejarah materi, motivasi pembelajaran, uraian materi, latihan soal, rangkuman, uji kompetensi, kunci jawaban, daftar pustaka, dan daftar penulis. Bahan ajar ini dikemas dengan mengkombinasikan beberapa konten text, gambar, dan animasi video. Bahan ajar ini dapat diunduh dengan mengikuti tahapan-tahapan pada buku panduan e-modul.

Adapun kegiatan yang dilakukan pada tahap awal yaitu menganalisis materi, bahan ajar yang telah ada, dan karakteristik peserta didik yang dilakukan dengan observasi dan wawancara tidak struktur. Hasil dari proses analisis dilanjutkan dengan perancangan desain komponen bahan ajar yang meliputi desain materi pembelajaran, desain kegiatan belajar, dan desain komponen bahan ajar.

Desain yang sudah terbentuk secara konseptual kemudian dikembangkan dengan menggunakan aplikasi 3d Pageflip Professional sehingga menghasilkan bahan ajar berbentuk emodul. Produk bahan ajar (e-modul) yang telah dikembangkan terlebih dahulu dilakukan tahap validasi materi dan validasi media. Validasi bahan ajar dilakukan untuk menguji layak atau tidaknya bahan ajar terebut digunakan. Hal ini dapat dilihat dari terpenuhi atau tidaknya bahan ajar tersebut terhadap standar penilaian kelayakan dari Badan Standar Nasional Pendidikan yang meliputi aspek 
kelayakan isi, aspek kelayakan bahasa, aspek kelayakan penyajian dan aspek kelayakan kegrafikan (Kantun \& Budiawati, 2016). Validasi dilakukan oleh dua orang dosen matematika dan satu orang guru matematika SMP. Hasil validasi e-modul secara keseluruhan menunjukkan bahwa bahan ajar matematika berbasis TIK menggunakan peta wilayah berada pada kategori sangat valid dengan ratarata keseluruhan aspek materi adalah $88,06 \%$ dan rata-rata keseluruhan pada aspek media adalah $87,71 \%$. Hal ini menunjukkan bahwa bahan ajar yang dikembangkan jika ditinjau dari penilaian materi maupun media dinyatakan valid dan layak digunakan sesuai dengan revisi yang disarankan validator.

Ada delapan aspek yang direvisi sesuai masukan dan saran dari validator, mulai dari pewarnaan bahan ajar, warna visible button, kesalahan penulisan, tampilan video dan lain sebagainya. Bahan ajar yang dinyatakan valid dan telah dilakukan revisi dilakukan pengujicobaan produk terhadap 6 orang peserta didik kelas VIII SMP Islam As-Shofa Pekanbaru yang masing masing 2 orang peserta didik berkemampuan tinggi, 2 orang peserta didik berkemampuan sedang, dan 2 orang peserta didik berkemampuan rendah. Uji coba dilakukan selama tiga hari yaitu tanggal 17,18 dan 19 Juni 2020.

Adapun data diperoleh pada tahap ujicoba produk yaitu penilaian peserta didik terhadap bahan ajar dengan menggunakan angket. Adapun aspek yang dinilai pada angket tersebut yaitu aspek kemudahan penggunaan, tampilan, penyajian, dan keterbacaan. Data hasil ujicoba digunakan untuk mengukur tingkat kepraktisan bahan ajar yang telah diujicobakan. Secara keseluruhan bahan ajar tersebut menunjukkan sudah sangat praktis dengan rata-rata $83.21 \%$. Hasil ujicoba menunjukkan bahwa bahan ajar tersebut sudah memenuhi syarat praktikalitas sehingga dapat dinyatakan layak digunakan.

\section{Pembahasan}

Penelitian ini mengembangkan suatu produk berupa bahan ajar matematika berbentuk emodul berbasis TIK yang menggunakan peta wilayah sebagai media penyampaian materi koordinat kartesius. Bahan ajar e-modul disusun dengan menggunakan software 3D Pageflip Professional. Emodul yang dihasilkan disajikan dalam bentuk aplikasi dengan format exe. dan .3dp. yang dapat di jalankan secara offline. Aplikasi e-modul dengan format .exe. dapat dijalankan tanpa menggunakan aplikasi bantuan sedangkan aplikasi e-modul dengan format .3dp. dapat dijalankan dengan terlebih dahulu mengistal aplikasi Flipbookreader.exe. Adapun kegiatan belajar yang disusun dalam e-modul yang dikembangkan untuk dapat memfasilitasi kemampuan pemahaman konsep matematis peserta didik pada materi koordinat kartesius.

Ada beberapa kelebihan dari e-modul yang dikembangkan ini yaitu tampilan dan visualisasi e-modul yang menarik. Materi pada e-modul ini divisualilasikan dalam bentuk teks, gambar dan video animasi. Video animasi menjelaskan setiap materi secara jelas dan terperinci. Peserta didik dapat mengontrol video secara langsung, baik untuk memutar, menjedah maupun memundurkan video 
sesuai dengan kebutuhannya. Bahasa yang digunakan dalam e-modul mudah dipahami. Tampilan gambar dapat diperbesar sesuai kebutuhan. Peserta didik dapat memperbesar atau memperkecilkan tampilan halaman dalam multi-level. Peserta didik dapat mengontrol tampilan halaman yang dikehendaki. E-modul dilengkapi dengan thumbnail halaman untuk membuka halaman yang diminati dengan cepat. E-modul juga dilengkapi dengan boormark halaman sebagai catatan untuk dibaca nanti.

Kelebihan-kelebihan tersebut sesuai dengan hasil penilaian yang diberikan oleh validator yang mana e-modul tersebut menunjukkan bahwa rata-rata keseluruhan aspek pada validasi materi adalah $88,06 \%$ dengan kategori sangat valid dan rata-rata keseluruhan pada aspek media adalah $87,71 \%$ dengan kategori sangat valid. Hal ini sejalan dengan penelitian yang dilakukan oleh (Juneri, J., Rozak, A., \& Pramuditya, 2019) mengenai bahan ajar digital materi fungsi. Dalam penelitian tersebut menjelaskan bahwa bahan ajar digital yang dikembangkan dengan berbantuan software $3 D$ Pageflip Professional pada materi fungsi dinyatakan sangat valid baik penilaian dari aspek materi maupun aspek media.

Bahan ajar matematika berbasis TIK menggunakan peta wilayah yang dinyatakan valid, diujicobakan kepada enam peserta didik SMP Islam As-Shofa Pekanbaru. Adapun hasil yang diperoleh dari angket respon peserta didik yang menunjukkan bahan ajar yang dikembangkan dinilai sudah sangat praktis dengan rata-rata $83.21 \%$.

Kepraktisan e-modul yang dikembangkan dibuktikan dengan Peserta didik merasa lebih menarik dan menyenangkan jika pembelajaran menggunakan e-modul yang dikembangkan. Peserta didik juga merasa materi mudah dipahami karena adanya visualisasi materi dalam bentuk video animasi yang menjelaskan materi secara jelas dan terperinci serta mudah untuk diputar ulang kembali sehingga dapat menyesuaikan tingkat kepahaman mereka. Hal ini menjadi salah satu keunggulan bahan ajar yang dikembangkan dengan berbantuan software 3D Pageflip Professional yaitu dengan perpaduan antar teks, gambar, dan video animasi akan menjadikan kegiatan belajar mengajar tidak monoton dan lebih menarik serta menyenangkan sehingga peserta didik termotivasi dan mudah untuk memahami materi pelajaran ((Andani, 2020), (Sugianto et al., 2013), (Maryam et al., 2019)). Adapun keunggulan lainnya dari e-modul yang dikembangkan yaitu e-modul dapat membantu peserta didik belajar secara mandiri sebagaimana yang dikatakan oleh peserta didik dapat belajar secara mandiri dengan menggunakan modul elektronik sehingga guru hanya berperan sebagai fasilitator dalam kegiatan pembelajaran (Syahrial et al., 2019).

Kegiatan belajar pada e-modul ini, materi disajikan dengan menggunakan peta wilayah sebagai medianya. Konsep dan prinsip materi koordinat kartesius disampaikan secara sederhana dengan menggunakan peta yang dikemas dalam bentuk visualisasi video animasi sehingga menjadikan materi koordinat kartesius bermakna. Hal ini juga menjadikan peserta didik mendapatkan pengalaman belajar yang baik untuk mengkontruksi pengetahuannya sehingga peserta didik mampu mendapatkan sendiri konsep dari materi yang dipelajari ((Rahmiah, N. F. N., \& Mustamin, 2012),(Hidayat, 2018), (Darmawan, 2016)). Hal sesuai dengan pendapat (Rogness, 2011), yang 
menyatakan peserta didik dapat terbantu dalam meningkatkan pemahaman konsep dengan penggunaan visualisasi. Visualisasi tersebut dapat berbentuk video animasi (Gambari et al., 2014). Pendapat lainnya juga sejalan yaitu dari (Imansari \& Sunaryantiningsih, 2017) yang menyatakan bahwa keberadaan e-modul yang mengombinasikan teks, gambar, dan video animasi yang dapat di tampilkan melalui komputer dapat meningkatkan pemahaman konsep dan hasil belajar peserta didik.

\section{KESIMPULAN}

Berdasarkan hasil validasi dan ujicoba dapat disimpulkan bahwa e-modul yang produk berupa bahan ajar matematika berbasis teknologi informasi dan komunikasi (TIK) menggunakan peta wilayah Riau untuk menfasilitasi kemampuan pemahaman konsep dinyatakan valid dan praktis sehingga layak di gunakan dalam proses pembelajaran.

\section{UCAPAN TERIMA KASIH}

Kami ucapkan terimakasih kepada Kepala Sekolah dan guru bidang studi matematika yang telah memberikan izin kepada peneliti untuk mengambil data dan kepada siswa SMP Islam As-Shofa yang telah bersedia membantu dalam pelaksanaan penelitian ini.

\section{REFERENSI}

Andani, M. (2020). E-Modul Fisika Dasar I Berbasis 3D Pageflip Professional. Schrodinger: Journal of Physics Education, 1(2).

Bagja Waluya. (2015). Peta, Globe, dan Atlas. Direktorat UPI.

Basaria, R., Setiawan, A., Sediyono, E., Matematika, P. S., \& Informasi, F. T. (2018). Penentuan luas wilayah kabupaten dan kota di provinsi sulawesi tengah menggunakan metode poligon dengan bantuan google earth. Jurnal Mercumatika.

Darmawan, H. (2016). Pembelajaran Berbasis Konstruktivisme Menggunakan Media Animasi dengan Kerangka Kerja TPCK dan Gaya Belajar Terhadap Prestasi Belajar Siswa. Formatif: Jurnal Ilmiah Pendidikan MIPA, 6(1), 1-11. https://doi.org/10.30998/formatif.v6i1.747

Gambari, A. I., Falode, C. O. \&, \& Adegbenro, D. A. (2014). Effectiveness of computer animation and geometrical instructional model on mathematics achievement and retention among junior secondary school students. In European Journal of Science and Mathematics Education.

Hidayat, A. (2018). PENGGUNAAN MEDIA PETA PENGARUHNYA TERHADAP MOTIVASI BELAJAR SEJARAH PADA SMA ISLAM PB. SOEDIRMAN CIJANTUNG JAKARTA TIMUR. Jurnal Candrasangkala Pendidikan Sejarah, 4(1), 14-20. https://doi.org/10.30870/candrasangkala.v4i1.3427

Hidayati, A. Bentri, A. Sunarti, V. (2019). Analysis of Training Needs for Making Teaching Materials Based on Information Technology For Elemetary School Teachers In Padang Pariaman Regency. Jurnal Spektrum, https://doi.org/https://doi.org/10.24036/spektrumpls.v2i3.106240

Ianah, I., \& Raharjo, H. (2014). Pengembangan Bahan Ajar Berbasis Komputer dalam Pembelajaran Matematika Pada Pokok Bahasan Kubus dan Balok. Eduma: Mathematics Education Learning and Teaching, 3(2), 119-132. https://doi.org/10.24235/eduma.v3i2.59 
Imansari, N., \& Sunaryantiningsih, I. (2017). Pengaruh Penggunaan E-Modul Interaktif Terhadap Hasil Belajar Mahasiswa pada Materi Kesehatan dan Keselamatan Kerja. VOLT : Jurnal Ilmiah Pendidikan Teknik Elektro, 2(1), 11-16. https://doi.org/10.30870/volt.v2i1.1478

Juneri, J., Rozak, A., \& Pramuditya, S. A. (2019). Desain Bahan Ajar Digital Materi Fungsi Berbasis Kemampuan Komunikasi Matematis. In Prosiding Seminar Nasional Pendidikan Matematika, $1(1)$.

Kantun, S., \& Budiawati, Y. S. R. (2016). Analisis Tingkat Kelayakan Bahan Ajar Ekonomi yang Digunakan Oleh Guru di SMA Negeri 4 Jember. JURNAL PENDIDIKAN EKONOMI: Jurnal Ilmiah Ilmu Pendidikan, Ilmu Ekonomi Dan Ilmu Sosial, 9(1).

Macarandang, M. A. (2009). Evaluation of a Proposed Set of Modules in Principles and Methods of Teaching. E-International Scientific Research Journal, 1(1), 1-24. http://citeseerx.ist.psu.edu/viewdoc/download;jsessionid=C3C3153AABC2B7F4E9BF2CED7C E2095D?doi=10.1.1.682.3739\&rep=rep1\&type=pdf

Majid, A. (2013). Perencanaan Pembelajaran Mengembangkan Kompetensi Guru. PT. Remaja Rosdakarya.

Mardyansyah, Y., Asrizal, \& Yulkifli. (2013). Pembuatan Modul Fisika Berbasis TIK Untuk Mengintegrasikan Nilai Pendidikan Karakter Dalam Pembelajaran Siswa SMAN 10 Padang Kelas X Semester 1. PILLAR OF PHYSICS EDUCATION, 1(1), 30-38.

Maryam, M., Masykur, R., \& Andriani, S. (2019). Pengembangan e-modul matematika berbasis Open Ended pada materi sistem persamaan linear dua variabel kelas VIII. AKSIOMA: Jurnal Matematika Dan Pendidikan Matematika, 10(1). https://doi.org/10.26877/aks.v10i1.3059

Mawarni, S., \& Muhtadi, A. (2017). Pengembangan digital book interaktif mata kuliah pengembangan multimedia pembelajaran interaktif untuk mahasiswa teknologi pendidikan. Jurnal Inovasi Teknologi Pendidikan, 4(1), 84-96. https://doi.org/10.21831/jitp.v4i1.10114

Mudlofir, A. (2011). Aplikasi Pengembangan Kurikulum Tingkat Satuan Pendidikan dan Bahan Ajar. Raja Grafindo Persada.

Novitasari, D. (2016). PENGARUH PENGGUNAAN MULTIMEDIA INTERAKTIF TERHADAP KEMAMPUAN PEMAHAMAN KONSEP MATEMATIS SISWA. FIBONACCI: Jurnal Pendidikan Matematika Dan Matematika. https://doi.org/10.24853/fbc.2.2.8-18

Nurhamdiah, N., Maimunah, M., \& Roza, Y. (2020). Praktikalitas bahan ajar matematika terintegrasi nilai islam menggunakan pendekatan saintifik untuk pengembangan karakter peserta didik. Jurnal Cendekia : Jurnal Pendidikan Matematika. https://doi.org/10.31004/cendekia.v4i1.170

Nurjehan, R. (2017). Penerapan CTL Berbasis Budaya Melayu Pada Pembelajaran Matematika Di Kelas VIII. Jurnal Pigur, 2(1), 144-152.

Peraturan Daerah Provinsi Riau No. 12. (2013). tentang penyelenggaraan pendidikan.

Peraturan Menteri Pendidikan dan Kebudayaan. (2013). Nomor 81A Tentang Implementasi Kurikulum.

Peraturan Menteri Pendidikan dan Kebudayaan No.22. (2016). Tentang Standar Proses Pendidikan Dasar dan Menengah.

Peraturan menteri pendidikan No. 79. (2014).

Rahmadani, H., Roza, Y., \& Murni, A. (2018). Analisis Kebutuhan Bahan Ajar Matematika Berbasis Teknologi Informasi di SMA IT Albayyinah Pekanbaru. JURING (Journal for Research in 
Mathematics Learning), 1(1), 91-98. https://doi.org/10.24014/juring.v1i1.5230

Rahmiah, N. F. N., \& Mustamin, N. F. N. (2012). Peta Buatan untuk Peningkatan Efektivitas Proses Belajar Sistem Koordinat Cartesius. Journal of Education and Learning, 6(2), 99-108.

Richard. E. Mayer. (2009). Multimedia Learning. Pustaka Pelajar.

Riduwan. (2013). Belajar Mudah Penelitian. Alfabeta.

Rogness, J. (2011). Mathematical Visualization. Journal of Mathematics Education at Teachers College, 2(2). https://doi.org/https://doi.org/10.7916/jmetc.v2i2.716

Roza, Y., Daqiqil, I., Siregar, S. N., Salam, S., \& Adnan, A. (2018). Android based e-learning tutorial for mathematics teachers. Journal of Physics: Conference Series. https://doi.org/10.1088/1742$6596 / 1088 / 1 / 012005$

Sa'adul Akbar. (2013). Instrumen Perangkat Pembelajaran. PT. Remaja Rosdakarya.

Said, F., Wahidiyat, A., Andayani, D. D., Harifuddin, H., \& Salam, R. (2017). Development of Travel Attractions through the Design of Google SketchUp Based Coastal Tourist Map (Pengembangan Daya Tarik Wisata melalui Perancangan Peta Wisata Pantai Berbasis Google SketchUp). Journal Pekommas, 2(2), 185-192. https://doi.org/10.30818/jpkm.2017.2020209

Sugianto, D., Abdullah, A. G., Elvyanti, S., \& Muladi, Y. (2013). Modul Vitual: Multimedia Flipbook Dasar Teknik Digital. Innovation of Vocational Technology Education, 9(2). https://doi.org/10.17509/invotec.v9i2.4860

Sulistyosari, Y. (2018). Kreativitas Guru Dalam Mengembangkan Bahan Ajar IPS Pada SMP/MTS Se-Kecamatan Ngadirejo Kabupaten Temanggung. Harmony Journal, 3(2), 178-189.

Syahrial, Asrial, Kurniawan, D. A., \& Piyana, S. O. (2019). E-Modul Etnokontruktivisme: Implementasi Pada Kelas V Sekolah Dasar Ditinjau Dari Persepsi, Minat Dan Motivasi. JTP Jurnal Teknologi Pendidikan, 21(2), 165-177. https://doi.org/10.21009/jtp.v21i2.11030

Syaiful, S. (2008). Silabus sebagai landasan pelaksanaan dan pengembangan pembelajaran bagi guru yang profesional. JURNAL TABULARASA PPS UNIMED.

Tekege, M. (2017). Pemanfaatan teknologi informasi dan komunikasi dalam pembelajaran SMA YPPGI Nabire. Jurnal Teknologi Dan Rekayasa. 